\title{
SLC15 family of peptide transporters (version 2019.4) in the IUPHAR/BPS Guide to Pharmacology Database
}

\author{
David T. Thwaites ${ }^{1}$ and Tiziano Verri ${ }^{2}$
}

1. Newcastle University, UK

2. University of Salento, Italy

\begin{abstract}
The Solute Carrier 15 (SLC15) family of peptide transporters, alias $\mathrm{H}^{+}$-coupled oligopeptide cotransporter family, is a group of membrane transporters known for their key role in the cellular uptake of di- and tripeptides (di/tripeptides). Of its members, SLC15A1 (PEPT1) chiefly mediates intestinal absorption of luminal di/tripeptides from overall dietary protein digestion, SLC15A2 (PEPT2) mainly allows renal tubular reuptake of di/tripeptides from ultrafiltration and brain-to-blood efflux of di/tripeptides in the choroid plexus, SLC15A3 (PHT2) and SLC15A4 (PHT1) interact with both di/tripeptides and histidine, e.g. in certain immune cells, and SLC15A5 has unknown physiological function. In addition, the SLC15 family of peptide transporters variably interacts with a very large number of peptidomimetics and peptide-like drugs. It is conceivable, based on the currently acknowledged structural and functional differences, to divide the SLC15 family of peptide transporters into two subfamilies.
\end{abstract}

\section{Contents}

This is a citation summary for SLC15 family of peptide transporters in the Guide to Pharmacology database (GtoPdb). It exists purely as an adjunct to the database to facilitate the recognition of citations to and from the database by citation analyzers. Readers will almost certainly want to visit the relevant sections of the database which are given here under database links.

GtoPdb is an expert-driven guide to pharmacological targets and the substances that act on them. GtoPdb is a reference work which is most usefully represented as an on-line database. As in any publication this work should be appropriately cited, and the papers it cites should also be recognized. This document provides a citation for the relevant parts of the database, and also provides a reference list for the research cited by those parts.

Please note that the database version for the citations given in GtoPdb are to the most recent preceding version in which the family or its subfamilies and targets were substantially changed. The links below are to the current version. If you need to consult the cited version, rather than the most recent version, please contact the GtoPdb curators.

\section{Database links}

SLC15 family of peptide transporters

http://www.guidetopharmacology.org/GRAC/FamilyDisplayForward?familyld=187 


\section{Transporters}

PEPT1(Peptide transporter 1)

http://www.guidetopharmacology.org/GRAC/ObjectDisplayForward?objectld=984

PEPT2(Peptide transporter 2)

http://www.guidetopharmacology.org/GRAC/ObjectDisplayForward?objectld=985

PHT2(Peptide transporter 3)

http://www.guidetopharmacology.org/GRAC/ObjectDisplayForward?objectld=986

PHT1(Peptide transporter 4)

http://www.guidetopharmacology.org/GRAC/ObjectDisplayForward?objectld=987

\section{References}

1. Agu R, Cowley E, Shao D, Macdonald C, Kirkpatrick D, Renton K and Massoud E. (2011) Proton-coupled oligopeptide transporter (POT) family expression in human nasal epithelium and their drug transport potential. Mol. Pharm. 8: 664-72 [PMID:21366347]

2. Anand BS, Patel J and Mitra AK. (2003) Interactions of the dipeptide ester prodrugs of acyclovir with the intestinal oligopeptide transporter: competitive inhibition of glycylsarcosine transport in human intestinal cell line-Caco-2. J. Pharmacol. Exp. Ther. 304: 781-91 [PMID:12538834]

3. Anderson CM, Jevons M, Thangaraju M, Edwards N, Conlon NJ, Woods S, Ganapathy V and Thwaites DT. (2010) Transport of the photodynamic therapy agent 5 -aminolevulinic acid by distinct $\mathrm{H}+$-coupled nutrient carriers coexpressed in the small intestine. J. Pharmacol. Exp. Ther. 332: 220-8 [PMID:19789362]

4. Balimane PV, Tamai I, Guo A, Nakanishi T, Kitada H, Leibach FH, Tsuji A and Sinko PJ. (1998) Direct evidence for peptide transporter (PepT1)-mediated uptake of a nonpeptide prodrug, valacyclovir. Biochem. Biophys. Res. Commun. 250: 246-51 [PMID:9753615]

5. Bhardwaj RK, Herrera-Ruiz D, Eltoukhy N, Saad M and Knipp GT. (2006) The functional evaluation of human peptide/histidine transporter 1 (hPHT1) in transiently transfected COS-7 cells. Eur J Pharm Sci 27: 533-42 [PMID:16289537]

6. Biegel A, Gebauer S, Hartrodt B, Brandsch M, Neubert K and Thondorf I. (2005) Three-dimensional quantitative structure-activity relationship analyses of beta-lactam antibiotics and tripeptides as substrates of the mammalian H+/peptide cotransporter PEPT1. J. Med. Chem. 48: 4410-9 [PMID:15974593]

7. Biegel A, Knütter I, Hartrodt B, Gebauer S, Theis S, Luckner P, Kottra G, Rastetter M, Zebisch K and Thondorf I et al.. (2006) The renal type $\mathrm{H}+$ /peptide symporter PEPT2: structure-affinity relationships. Amino Acids 31: 137-56 [PMID:16868651]

8. Buyse M, Berlioz F, Guilmeau S, Tsocas A, Voisin T, Péranzi G, Merlin D, Laburthe M, Lewin MJ and Rozé $C$ et al.. (2001) PepT1-mediated epithelial transport of dipeptides and cephalexin is enhanced by luminal leptin in the small intestine. J. Clin. Invest. 108: 1483-94 [PMID:11714740]

9. Chu XY, Sánchez-Castaño GP, Higaki K, Oh DM, Hsu CP and Amidon GL. (2001) Correlation between epithelial cell permeability of cephalexin and expression of intestinal oligopeptide transporter. $J$. Pharmacol. Exp. Ther. 299: 575-82 [PMID:11602669]

10. Covitz KM, Amidon GL and Sadée W. (1996) Human dipeptide transporter, hPEPT1, stably transfected into Chinese hamster ovary cells. Pharm. Res. 13: 1631-4 [PMID:8956326]

11. Darcel NP, Liou AP, Tomé D and Raybould HE. (2005) Activation of vagal afferents in the rat duodenum by protein digests requires PepT1. J. Nutr. 135: 1491-5 [PMID:15930458]

12. Dieck ST, Heuer H, Ehrchen J, Otto C and Bauer K. (1999) The peptide transporter PepT2 is expressed in rat brain and mediates the accumulation of the fluorescent dipeptide derivative beta-Ala-Lys-Nepsilon-

AMCA in astrocytes. Glia 25: 10-20 [PMID:9888294]

13. Döring F, Walter J, Will J, Föcking M, Boll M, Amasheh S, Clauss W and Daniel H. (1998) Deltaaminolevulinic acid transport by intestinal and renal peptide transporters and its physiological and clinical implications. J. Clin. Invest. 101: 2761-7 [PMID:9637710]

14. Ganapathy ME, Huang W, Rajan DP, Carter AL, Sugawara M, Iseki K, Leibach FH and Ganapathy V. (2000) beta-lactam antibiotics as substrates for OCTN2, an organic cation/carnitine transporter. J. Biol. 
Chem. 275: 1699-707 [PMID:10636865]

15. Ganapathy ME, Prasad PD, Mackenzie B, Ganapathy V and Leibach FH. (1997) Interaction of anionic cephalosporins with the intestinal and renal peptide transporters PEPT 1 and PEPT 2. Biochim. Biophys. Acta 1324: 296-308 [PMID:9092716]

16. Han H, de Vrueh RL, Rhie JK, Covitz KM, Smith PL, Lee CP, Oh DM, Sadée W and Amidon GL. (1998) 5'Amino acid esters of antiviral nucleosides, acyclovir, and AZT are absorbed by the intestinal PEPT1 peptide transporter. Pharm. Res. 15: 1154-9 [PMID:9706043]

17. Hu Y, Xie Y, Keep RF and Smith DE. (2014) Divergent developmental expression and function of the proton-coupled oligopeptide transporters PepT2 and PhT1 in regional brain slices of mouse and rat. $J$. Neurochem. 129: 955-65 [PMID:24548120]

18. Irie M, Terada T, Sawada K, Saito H and Inui K. (2001) Recognition and transport characteristics of nonpeptidic compounds by basolateral peptide transporter in Caco-2 cells. J. Pharmacol. Exp. Ther. 298: 711-7 [PMID:11454935]

19. Jappar D, Wu SP, Hu Y and Smith DE. (2010) Significance and regional dependency of peptide transporter (PEPT) 1 in the intestinal permeability of glycylsarcosine: in situ single-pass perfusion studies in wild-type and Pept1 knockout mice. Drug Metab. Dispos. 38: 1740-6 [PMID:20660104]

20. Knütter I, Hartrodt B, Theis S, Foltz M, Rastetter M, Daniel H, Neubert K and Brandsch M. (2004) Analysis of the transport properties of side chain modified dipeptides at the mammalian peptide transporter PEPT1. Eur J Pharm Sci21: 61-7 [PMID:14706812]

21. Knütter I, Kottra G, Fischer W, Daniel H and Brandsch M. (2009) High-affinity interaction of sartans with H+/peptide transporters. Drug Metab. Dispos. 37: 143-9 [PMID:18824524]

22. Knütter I, Theis S, Hartrodt B, Born I, Brandsch M, Daniel H and Neubert K. (2001) A novel inhibitor of the mammalian peptide transporter PEPT1. Biochemistry 40: 4454-8 [PMID:11284702]

23. Knütter I, Wollesky C, Kottra G, Hahn MG, Fischer W, Zebisch K, Neubert RH, Daniel H and Brandsch M. (2008) Transport of angiotensin-converting enzyme inhibitors by $\mathrm{H}+$ /peptide transporters revisited. $J$. Pharmacol. Exp. Ther. 327: 432-41 [PMID:18713951]

24. Kobayashi T, Shimabukuro-Demoto S, Yoshida-Sugitani R, Furuyama-Tanaka K, Karyu H, Sugiura Y, Shimizu Y, Hosaka T, Goto M and Kato N et al.. (2014) The histidine transporter SLC15A4 coordinates mTOR-dependent inflammatory responses and pathogenic antibody production. Immunity 41: 375-88 [PMID:25238095]

25. Kottra G, Spanier B, Verri T and Daniel H. (2013) Peptide transporter isoforms are discriminated by the fluorophore-conjugated dipeptides $\beta$-Ala- and d-Ala-Lys-N-7-amino-4-methylcoumarin-3-acetic acid. Physiol Rep 1: e00165 [PMID:24744852]

26. Lee J, Tattoli I, Wojtal KA, Vavricka SR, Philpott DJ and Girardin SE. (2009) pH-dependent internalization of muramyl peptides from early endosomes enables Nod1 and Nod2 signaling. J. Biol. Chem. 284: 2381829 [PMID:19570976]

27. Li M, Anderson GD, Phillips BR, Kong W, Shen DD and Wang J. (2006) Interactions of amoxicillin and cefaclor with human renal organic anion and peptide transporters. Drug Metab. Dispos. 34: 547-55 [PMID:16434549]

28. Luckner $P$ and Brandsch M. (2005) Interaction of 31 beta-lactam antibiotics with the $\mathrm{H}_{+} /$peptide symporter PEPT2: analysis of affinity constants and comparison with PEPT1. Eur J Pharm Biopharm 59: 17-24 [PMID:15567297]

29. Mandal A, Pal D and Mitra AK. (2016) Circumvention of P-gp and MRP2 mediated efflux of lopinavir by a histidine based dipeptide prodrug. Int J Pharm 512: 49-60 [PMID:27543355]

30. Meredith D, Boyd CA, Bronk JR, Bailey PD, Morgan KM, Collier ID and Temple CS. (1998) 4aminomethylbenzoic acid is a non-translocated competitive inhibitor of the epithelial peptide transporter PepT1. J. Physiol. (Lond.) 512 ( Pt 3): 629-34 [PMID:9882198]

31. Merlin D, Steel A, Gewirtz AT, Si-Tahar M, Hediger MA and Madara JL. (1998) hPepT1-mediated epithelial transport of bacteria-derived chemotactic peptides enhances neutrophil-epithelial interactions. $J$. Clin. Invest. 102: 2011-8 [PMID:9835627] 
32. Mitsuoka K, Miyoshi S, Kato Y, Murakami Y, Utsumi R, Kubo Y, Noda A, Nakamura Y, Nishimura S and Tsuji A. (2008) Cancer detection using a PET tracer, 11C-glycylsarcosine, targeted to $\mathrm{H}+$ /peptide transporter. J. Nucl. Med. 49: 615-22 [PMID:18344442]

33. Nakamura N, Lill JR, Phung Q, Jiang Z, Bakalarski C, de Mazière A, Klumperman J, Schlatter M, Delamarre L and Mellman I. (2014) Endosomes are specialized platforms for bacterial sensing and NOD2 signalling. Nature 509: 240-4 [PMID:24695226]

34. Neumann J, Bruch M, Gebauer S and Brandsch M. (2004) Transport of the phosphonodipeptide alafosfalin by the $\mathrm{H}+$ /peptide cotransporters PEPT1 and PEPT2 in intestinal and renal epithelial cells. Eur. J. Biochem. 271: 2012-7 [PMID:15128310]

35. Otter M, Oswald S, Siegmund W and Keiser M. (2017) Effects of frequently used pharmaceutical excipients on the organic cation transporters $1-3$ and peptide transporters $1 / 2$ stably expressed in MDCKII cells. Eur J Pharm Biopharm 112: 187-195 [PMID:27903454]

36. Romano A, Barca A, Kottra G, Daniel H, Storelli C and Verri T. (2010) Functional expression of SLC15 peptide transporters in rat thyroid follicular cells. Mol. Cell. Endocrinol. 315: 174-81 [PMID:19913073]

37. Sakata K, Yamashita T, Maeda M, Moriyama Y, Shimada S and Tohyama M. (2001) Cloning of a lymphatic peptide/histidine transporter. Biochem. J. 356: 53-60 [PMID:11336635]

38. Sala-Rabanal M, Loo DD, Hirayama BA, Turk E and Wright EM. (2006) Molecular interactions between dipeptides, drugs and the human intestinal $\mathrm{H}+$-oligopeptide cotransporter hPEPT1. J. Physiol. (Lond.) 574: 149-66 [PMID:16627568]

39. Sasawatari S, Okamura T, Kasumi E, Tanaka-Furuyama K, Yanobu-Takanashi R, Shirasawa S, Kato N and Toyama-Sorimachi N. (2011) The solute carrier family 15A4 regulates TLR9 and NOD1 functions in the innate immune system and promotes colitis in mice. Gastroenterology 140: 1513-25 [PMID:21277849]

40. Sawada K, Terada T, Saito H, Hashimoto $Y$ and Inui K. (1999) Effects of glibenclamide on glycylsarcosine transport by the rat peptide transporters PEPT1 and PEPT2. Br. J. Pharmacol. 128: 1159-64 [PMID:10578127]

41. Song F, Yi Y, Li C, Hu Y, Wang J, Smith DE and Jiang H. (2018) Regulation and biological role of the peptide/histidine transporter SLC15A3 in Toll-like receptor-mediated inflammatory responses in macrophage. Cell Death Dis 9: 770 [PMID:29991810]

42. Sreedharan S, Stephansson O, Schiöth HB and Fredriksson R. (2011) Long evolutionary conservation and considerable tissue specificity of several atypical solute carrier transporters. Gene 478: 11-8 [PMID:21044875]

43. Sun D, Wang Y, Tan F, Fang D, Hu Y, Smith DE and Jiang H. (2013) Functional and molecular expression of the proton-coupled oligopeptide transporters in spleen and macrophages from mouse and human. Mol. Pharm. 10: 1409-16 [PMID:23442152]

44. Tai W, Chen Z and Cheng K. (2013) Expression profile and functional activity of peptide transporters in prostate cancer cells. Mol. Pharm. 10: 477-87 [PMID:22950754]

45. Tamai I, Nakanishi T, Hayashi K, Terao T, Sai Y, Shiraga T, Miyamoto K, Takeda E, Higashida H and Tsuji A. (1997) The predominant contribution of oligopeptide transporter PepT1 to intestinal absorption of beta-lactam antibiotics in the rat small intestine. J. Pharm. Pharmacol. 49: 796-801 [PMID:9379359]

46. Terada T, Saito H, Mukai M and Inui K. (1997) Recognition of beta-lactam antibiotics by rat peptide transporters, PEPT1 and PEPT2, in LLC-PK1 cells. Am. J. Physiol. 273: F706-11 [PMID:9374833]

47. Terada T, Saito H, Mukai M and Inui KI. (1996) Identification of the histidine residues involved in substrate recognition by a rat $\mathrm{H}+$ /peptide cotransporter, PEPT1. FEBS Lett. 394: 196-200 [PMID:8843163]

48. Terada T, Sawada K, Saito H, Hashimoto Y and Inui K. (2000) Inhibitory effect of novel oral hypoglycemic agent nateglinide (AY4166) on peptide transporters PEPT1 and PEPT2. Eur. J. Pharmacol. 392: 11-7 [PMID:10748266]

49. Theis $S$, Hartrodt B, Kottra G, Neubert $K$ and Daniel H. (2002) Defining minimal structural features in substrates of the $\mathrm{H}(+) /$ peptide cotransporter PEPT2 using novel amino acid and dipeptide derivatives. Mol. Pharmacol. 61: 214-21 [PMID:11752223]

50. Vavricka SR, Musch MW, Chang JE, Nakagawa Y, Phanvijhitsiri K, Waypa TS, Merlin D, Schneewind O 
and Chang EB. (2004) hPepT1 transports muramyl dipeptide, activating NF-kappaB and stimulating IL-8 secretion in human colonic Caco2/bbe cells. Gastroenterology 127: 1401-9 [PMID:15521010]

51. Wang XX, Hu Y, Keep RF, Toyama-Sorimachi N and Smith DE. (2017) A novel role for PHT1 in the disposition of I-histidine in brain: In vitro slice and in vivo pharmacokinetic studies in wildtype and Pht1 null mice. Biochem. Pharmacol. 124: 94-102 [PMID:27845049]

52. Wu SP and Smith DE. (2013) Impact of intestinal PepT1 on the kinetics and dynamics of N-formylmethionyl-leucyl-phenylalanine, a bacterially-produced chemotactic peptide. Mol. Pharm. 10: 677-84 [PMID:23259992]

53. Yamashita T, Shimada S, Guo W, Sato K, Kohmura E, Hayakawa T, Takagi T and Tohyama M. (1997) Cloning and functional expression of a brain peptide/histidine transporter. J. Biol. Chem. 272: 10205-11 [PMID:9092568] 